\title{
Perbandingan Tipe Metode PoS Tagger Terhadap Nilai Akurasi Untuk Bahasa Melayu Pontianak
}

\author{
Ade Sumoko $^{1}$, Arif Bijaksana Putra Negara ${ }^{2}$, Helen Sasty Pratiwi ${ }^{3}$ \\ ${ }^{a}$ Program Studi Informatika, Fakultas Teknik, Universitas Tanjungpura \\ Jl. Prof. Dr. H. Hadari Nawawi, Pontianak 78124 \\ 1ade.sumokodstudent.untan.ac.id \\ 2arifbpn@gmail.com \\ 3helensastypratiwi@gmail.com
}

\begin{abstract}
Abstrak
Metode PoS Tagger adalah metode yang digunakan sebagai acuan untuk melakukan tagging pos secara langsung sesuai dengan data uji yang dan data latih yang telah dilakukan pengujian untuk mendeteksi seberapa akurat metode pos tagger tersebut dalam melakukan tagging, yang dimana hal ini lakukan pengecekan dengan data tagging secara manual untuk melihat kearutan dari metode tersebut. Data kalimat teks korpus yang digunakan sebanyak 1500 kalimat bahasa Melayu Pontianak yang dimana kalimat teks digunakan dalam penelitian ini sebagai kalimat latih maupun kalimat uji. Penelitian ini melakukan pengembangan korpus yang awalnya berjumlah 500 kalimat menjadi 1500 kalimat, dan pengembangan tag PoS yang menggunakan data tag PoS dari penelitian lainnya kemudian hasil dari analisa penelitian ini adalah mendapatkan nilai akurasi dari setiap metode PoS tagger.
\end{abstract}

\section{Comparison Of The Type Of PoS Tagger Method To The Accuracy Value For Pontianak Melayu Language}

\begin{abstract}
PoS Tagger method is a method used as a reference for carrying out tagging PoS directly according to the test data and training data that has been tested to detect how accurate the PoS tagger method is in tagging, which is to check with tagging data manually to see the solubility of the method. Corpus text sentence data used were 1500 Bahasa Melayu Pontianak's sentences where the text sentences were used in this study as training sentences and test sentences. This study developed a corpus from 500 sentences to 1500 sentences, and developed a tag PoS that used tag PoS data from other studies. Then the results of the analysis of this study were to obtain the accuracy value of each PoS tagger method.
\end{abstract}

Keywords: PoS Tagger, Pontianak Melayu Language, PoS Tagger Method, Accuracy Value.

\section{Pendahuluan}

Bahasa merupakan salah satu alat komunikasi yang digunakan oleh manusia dalam kehidupan sehari-hari. Kemampuan penguasaan bahasa yang baik dapat mempermudah proses interaksi dengan orang lain. Bahasa Melayu Pontianak merupakan bahasa yang dituturkan oleh masyarakat Pontianak dalam kehidupan sehari-hari.

Penduduk asli Pontianak berdomisili dibeberapa kecamatan yang letaknya berdekatan dengan Keraton Kadariah yang merupakan pusat kerajaan Melayu di Pontianak. Bahasa Melayu Pontianak tidak hanya ada dan digunakan di daerah-daerah yang dekat dengan bermukimnya penduduk asli kota Pontianak. Bahasa Melayu Pontianak ini memang sangat jauh dari kepunahan, hal ini dikarenakan bahasa ini masih menjadi pilihan bahasa disituasi nonformal.

Untuk menghindari terjadinya kepunahan bahasa akibat ancaman dari bahasa lainnya tentunya diperlukan penerapan teknologi terbaru, seiring dengan perkembangan teknologi hal ini juga terpacu pada data dari hasil sensus penduduk yang telah dilakukan yang dimana pada data tersebut dapat menjadi salah satu acuan dari perkembangan atau penurunan dari bahasa yang terdapat di sebuah provinsi. Pelestarian kebudayaan bahasa daerah sangat diperlukan untuk mencegah ancaman dari globalisasi yang berdampak pada berkurangnya penutur dalam menggunakan bahasa Melayu Pontianak. Salah satunya dengan memanfaatkan teknologi saat ini yaitu Text To Speech (TTS).

Teknologi Text To Speech (TTS) merupakan sebuah teknologi yang dapat membangkitkan sintesa ucapan dengan mengubah teks menjadi suara atau ucapan yang meyerupai ucapan manusia (Pelton dalam buku "Voice Processing"). TTS mengkonversi teks dalam format suatu bahasa menjadi ucapan sesuai dengan teks dalam bahasa yang digunakan. TTS sendiri dapat diimplementasikan ke 
dalam suatu bentuk aplikasi telekomunikasi yang dapat mempermudah pekerjaan manusia.

POS (Part Of Speech) merupakan kelas kata yang dimana kelas kata ini yang dipahami oleh mesin untuk menentukan jenis dari kata-kata yang terdapat pada kalimat. PoS tag adalah suatu proses yang memberikan label kelas kata secara otomatis atau manual pada setiap kata yang ada pada suatu teks atau dokumen.

Pada penelitian sebelumnya terdapat jumlah PoS Tagger yang memiliki jumlah lebih dari 25 yang dimana tentunya hal ini akan memberikan beban pada saat proses perhitungan dan tingkat kecepatan juga akan menurun karena harus menghitung dengan jumlah PoS Tagger yang banyak atau diatas 25 . Oleh sebab itu, dalam penelitian ini, dilakukan perbandingan antara beberapa PoS Tagger kemudian dianalisa sehingga menghasilkan jumlah PoS Tagger yang berjumlah tidak lebih dari 25 dan tentunya akan dilakukan perbandingan tipe metode PoS Tagger terhadap nilai akurasi dari PoS Tagger yang telah dikembangkan.

\section{URAIAN PENELITIAN}

\section{A. Metodologi Penelitian}

Dalam penelitian ini dilakukan suatu proses secara ilmiah untuk keperluan penelitian. Metode tersebut digunakan untuk melakukan proses penelitian. Langkah penelitian dapat dilihat pada gambar 1 .

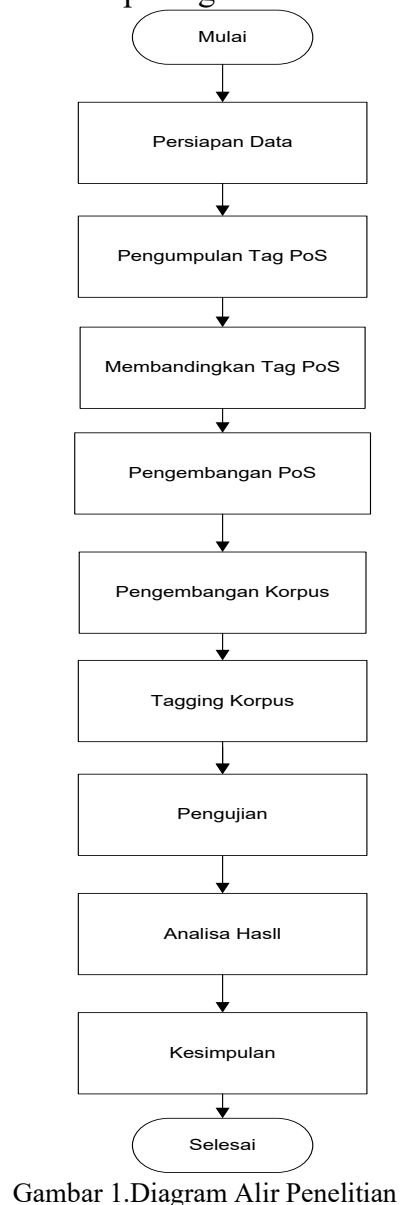

Gambar 1.Diagram Alir Penelitian

\section{Persiapan Data}

Persiapan data berupa teks kalimat bahasa Melayu Pontianak yang bersumber dari buku Sepok 3 karangan Pay Jarrot Sujarwo dan korpus dari penelitian sebelumnya yang berjumlah 500 kalimat. Jumlah kalimat yang digunakan pada penelitian sebanyak 1500 kalimat. Teks kalimat digunakan untuk penandaan PoS atau label kata.

2. Pengumpulan Tag PoS

Pengumpulan tag PoS dari penelitian sebelumnya, yang dimana penelitian proses pengumpulan tipe PoS ini terdari dari 10 penelitian sebelumnya, yaitu : tipe PoS Arawinda Dinakaramani(2014), tipe Pos Pisceldo(2009), tipe PoS Alfan Farizki Wicaksono(2010), tipe PoS Septina Dian Larasati(2011), tipe PoS Ayu Purwarianti(2010), tipe PoS Achmad Fatchuttaman Abka(2017), tipe PoS Andriani(2009), tipe PoS Setyaningsih(2017), tipe PoS Muliono(2012).

3. Membandingkan dan Mengembangkan Tag PoS

Pada tahap ini digunakan set PoS yang baru dibentuk berdasarkan Set PoS Bahasa Melayu Pontianak. Pengelompokkan kelas kata dalam Bahasa Melayu dilakukan secara manual dengan merujuk pada referensi tipe PoS Arawinda Dinakaramani(2014), tipe Pos Pisceldo(2009), tipe PoS Alfan Farizki Wicaksono(2010), tipe PoS Septina Dian Larasati(2011), tipe PoS Ayu Purwarianti(2010), tipe PoS Achmad Fatchuttaman Abka(2017), tipe PoS Andriani(2009), tipe PoS Setyaningsih(2017), tipe PoS Muliono(2012). Set PoS baru dibuat dengan tujuan untuk memperjelas penandaan tipe kata dalam kalimat dan meningkatkan akurasi prediksi jeda. Pembuatan tabel PoS bahasa Melayu Pontianak dilakukan dengan cara menganalisa tabel PoS referensi yang ada dan mencocokkan label PoS yang sesuai dengan kelas kata yang digunakan pada bahasa Melayu Pontianak. Penambahan set PoS disesuaikan dengan fungsi kata dalam kalimat bahasa Melayu Pontianak. Hasil dari pembuatan tabel PoS adalah tabel set PoS baru yang digunakan untuk menandai kata di korpus teks bahasa Melayu Pontianak. 4. Pengembangan Korpus

Peningkatan jumlah korpus dari penelitian sebelumnya yang hanya berjumlah 500 kalimat ditambah lagi dengan kalimat baru dari buku sepok tiga sehingga mendapatkan korpus yang dapat mewakili keseluruhan dari tag PoS yang sudah dibuat, sehingga korpus menjadi lebih maksimal untuk pengujian.

\section{Tagging Korpus}

Teks kalimat untuk korpus latih yang berasal dari penelitian sebelumnya diberikan tag PoS sesuai dengan kelas katanya secara manual sesuai set PoS yang telah dikembangkan. Penandaan PoS berdasarkan makna dari kata tersebut ketika diucapkan dan dari Kamus Besar Bahasa Indonesia (KBBI). Korpus latih tersebut berisikan "kata/PoS".

Misalkan pada korpus terdapat kalimat :

"Eh , jangan banyak umong kau .'

Setiap kata akan dilihat dan dikelompokkan berdasarkan label PoS. Misalkan kata "Eh" menunjukkan panggilan pada kalimat dengan kata seru sehingga ditandai dengan PoS "RP" untuk kata seru. Kata "jangan" menunjukkan kata negatif sehingga ditandai dengan PoS "NEG" untuk 
kata negatif. Kata "banyak" menunjukkan kata sifat sehingga ditandai dengan PoS "JJ" untuk kata sifat. Kata "ngumong" menunjukkan kegiatan berbicara sehingga ditandai dengan PoS "VB" untuk kata kerja intrasitif yang memerlukan objek dibelakang kata kerja. Kata "kau" merupakan objek yang berupa kata ganti orang sehingga ditandai dengan PoS "PRP" yang dikhususkan untuk kata ganti orang seperi "kau", "aku", "kamek". Hasil penandaan PoS menjadi kalimat yang berisi "kata/PoS" seperti berikut:

"Eh/RP ,/, jangan/NEG banyak/JJ umong/VB kau/PRP ./.“ 6. Pelatihan Korpus di IPOSTagger

Setelah korpus latih selesai dibuat, selanjutnya dilakukan proses pelatihan korpus pada IPOSTagger. Pada proses pelatihan korpus untuk tagging PoS, korpus latih yang berisi "kata/PoS" disimpan dalam folder IPOSTagger dengan ekstensi *.crp. Kemudian proses pelatihan dilakukan melalui command prompt pada folder IPOSTagger.

7. Pelatihan Korpus Bigram, Trigram, Perceptron, Unigram Setelah dilakukan pelatiahn korpus pada IPOSTagger yaitu pelatihan metode HMM, maka dilakukan pelatihan pada metode PoS Tagger lainnya. Pada pelatihan korpus untuk tagging PoS, korpus latih yang berisi "kata/PoS" disimpan pada folder masing-masing metode dengan nama file uji500.txt. kemudian proses pelatihan dilakukan melalui aplikasi phycharm community.

8. Perancangan Pengujian

Pengujian dilakukan untuk mendapatkan nilai pengujian yang akan dianalisis menjadi kesimpulan penelitian. Pengujian dilakukan dengan membandingkan kalimat asli dengan kalimat hasil prediksi jeda dari hasil implementasi rule jeda menggunakan pengujian Accuracy, Precision, Recall dan F-Score. Total kalimat yang akan diuji adalah 1500 kalimat bahasa Melayu Pontianak.

9. Analisis Hasil Pengujian

Pada tahap ini, hasil pengujian berupa nilai akurasi dari setiap metode nilai accuracy, precision, recall, dan $\mathrm{f}$ measure dianalisis secara keseluruhan untuk mempermudah penarikan kesimpulan.

10. Kesimpulan Hasil Pengujian

Kesimpulan dirumuskan berdasarkan dari perbandingan nilai akurasi dari setiap metode PoS Tagger, yang dimana setiap nilai dari metode ini berpengaruh dari seberapa tinggi nilai akurasi antara setiap metode yang diuji.

\section{B. Penelitian Terkait}

Beberapa penelitian terkait yang berhubungan dengan proses tagging PoS menggunakan metode PoS Tagger yang berhubungan dengan penelitian ini.

Evi Fahtiyah Muniyati dengan judul skripsi "Prediksi Jeda Dalam Ucapan Kalimat Bahasa Melayu Pontianak Menggunakan Hidden Markov Model Berbasis Part Of Speech" dengan jeda ucapan bigram nilai akurasi frasa jeda $1+2=30.8 \%$ dan akurasi jeda $2=80 \%$ dan dengan jeda ucapan trigram nilai akurasi jeda $1+2=30.8 \%$ dan akurasi jeda $2=81.4 \%$.

Yulia Magdalena dengan judul skripsi "Prediksi Jeda pada Ucapan Kalimat Bahasa Melayu Pontianak Menggunakan Metode Shallow Parsing dengan Pengembangan Rule Grammar dan Rule Jeda" dengan akurasi kecocokan pada satu kalimat sebesar 33.6\% dan nilai akurasi $70,2 \%$ jeda panjang atau sebanyak 364 kalimat dari 500 kalimat.

M. Iqbal Kamiludin dengan judul skripsi "Prediksi Jeda pada Ucapan Bahasa Melayu Pontianak dengan Menggunakan Metode Shallow Parsing” dengan nilai recall dan precision untuk kalimat tunggal sebesar 0.78 dan 0.74 , sedangkan untuk kalimat majemuk sebesar 0.67 dan 0.57. Dari 168 kalimat yang ada, nilai kecocokan dengan jeda penutur sebesar $40.4 \%$ atau 68 kalimat.

Adhitya Teguh Nugraha (2014), Teknik Informatika di Universitas Tanjungpura dalam skripsi yang berjudul "Prediksi Jeda dalam Ucapan Kalimat Bahasa Indonesia dengan Hidden Markov Model" menjelaskan bahwa tujuan penelitian tersebut adalah memprediksi terjadinya jeda pada ucapan kalimat berbahasa Indonesia dengan menggunakan Hidden Markov Model (HMM). Penelitian ini menghasilkan aplikasi untuk memprediksi jeda dalam ucapan kalimat berbahasa Indonesia dan menggunakan Delphi untuk membuat antarmuka sistem. Korpus yang digunakan berasal dari berita yang disiarkan oleh Lembaga Penyiaran Publik TVRI Kalimantan Barat. Penelitian ini menggunakan 35 tag PoS seperti yang digunakan pada penelitian milik Wicaksono dan Purwarianti (2010). Hasil dari penelitian ini yaitu nilai recall sebesar 0.132 , nilai precision sebesar 0.364 dan $f$ score sebesar 0.194

\section{Part Of Speech Tagging}

Part of speech (PoS) tagging adalah proses menentukan kelas kata untuk setiap kata dalam sebuah kalimat. Part of speech atau kelas kata terdiri dari kata kerja, kata sifat, kata benda, kata keterangan, dan lain-lain. Beberapa penggunaan PoS-tagging adalah untuk menghapus perbedaan yang tidak relevan, menghapus ambiguitas, membantu stemming, dan membantu pencarian kata benda (Christianti M, Pragantha dan Victor, 2016).

Hingga saat ini sudah ada beberapa set PoS berbahasa Indonesia yang dihasilkan dari penelitian sebelumnya, diantaranya yaitu tipe PoS Arawinda Dinakaramani(2014), tipe Pos Pisceldo(2009), tipe PoS Alfan Farizki Wicaksono(2010), tipe PoS Septina Dian Larasati(2011), tipe PoS Ayu Purwarianti(2010), tipe PoS Achmad Fatchuttaman Abka(2017), tipe PoS Andriani(2009), tipe PoS Setyaningsih(2017), tipe PoS Muliono(2012).

\section{Metode Pos Tagger}

Metode PoS Tagger yang digunakan pada penelitian ini adalah, Bigram, HMM, Perceptron, Trigram, Unigram. Penjelasan mengenai metode tagger adalah sebagai berikut :

1. Bigram

Brigram tagger adalah pada dasarnya bekerja dengan cara yang sama seperti unigram, perbedaannya adalah pada bigram tagger mempertimbangkan konteks kapan menetapkan tag ke kata, sehingga jika dijelaskan lebih rinci bigram adalah urutan dua eleman yang berdekatan dari untaian token yang biasanya berupa huruf, suku kata, atau kata yang dimana $n=2$.

\section{HMM (Hidden Markov Model)}


HMM dikembangkan dari Markov Chain yaitu keadaan yang akan datang dari suatu sequence tidak ditentukan dari keadaan saat ini, tapi juga perpindahan dari suatu state ke state sequence yang lain.

\section{Perceptron}

Perceptron tagger mengimplementasikan penandaan PoS (Part Of Speech) menggunakan rata-rata, struktur algoritma perceptron.

\section{Trigram}

Trigram tagger adalah sebuah tagger yang menggunakan dua kata sebagai konteksnya untuk menentukan Tag PoS(Part Of Speech), yang dimana $\mathrm{n}=3$.

5. Unigram

Unigram tagger adalah sebuah tagger yang hanya menggunakan satu kata sebagai konteksnya untuk menentukan Tag PoS(Part Of Speech), sederhananya tagger ini berbasis konteks yang konteksnya adalah satu kata, yaitu Unigram, yang dimana $\mathrm{n}=1$.

\section{E. Python}

Menurut Ljubomir Perkovic (2012), Python merupakan bahasa pemrograman dengan tujuan umum yang dikembangkan secara khusus untuk membuat source code mudah dibaca. Python juga memiliki library yang lengkap sehingga memungkinkan programmer untuk membuat aplikasi yang mutakhir dengan menggunakan source code yang tampak sederhana.

Salah satu kegunaan Bahasa Pemrograman Python yaitu dapat mendukung aktivitas pemrosesan Bahasa alami, dengan menggukan modul dari Natural Language Toolkit yang merupakan salah satu koponen yang disediakan oleh Bahasa pemrograman python, khususnya dalam pengolahan digital Bahasa alami. Dalam penelitian ini python digunakan sebagai Bahasa pemrograman dalam proses menentukaan frasa jeda ucapan pada kalimat dengan menggunakan fungsi shallow parsing yang merupakan salah satu tugas dari Natural Language Toolkit.

\section{F. Natural Language Toolkit}

Walaupun python memiliki kemampuan untuk melakukan tugas-tugas NLP (Natural Language Processing) secara dasar, namun tidak cukup efisien dalam melakukan tugas-tugas standar yang terdapat dalam NLP, maka dari itu digunakan modul NLTK (Natural Language Toolkit). Modul NLTK menyediakan berbagai fungsi dan wrapper, serta corpora standar baik itu mentah atau preprocessed yang digunakan dalam materi pengajaran NLP. NLTK sendiri merupakan sebuah platform yang dirilis oleh Steven Bird dan Edward Loper pada tahun 2001 yang digunakan untuk membangun program analisis teks. NLTK menyediakan antarmuka yang mudah digunakan untuk lebih dari 50 sumber korpora dan leksikal dan seperangkat pustaka (library) pemrosesan teks untuk klasifikasi (classification), tokenisasi (tokenization), penumpukan (stemming), penandaan (tagging), penguraian (parsing), penalaran semantik (semantic reasoning), pembungkus (wrapper) pustaka NLP dan forum diskusi aktif (Lestari, 2017).

\section{G. Bahasa Melayu Pontianak}

Bahasa Melayu Pontianak merupakan satu di antara banyak bahasa yang terdapat di Provinsi Kalimantan Barat. Bahasa ini dituturkan oleh orang Melayu yang ada di kota Pontianak. Penggunaan bahasa Melayu Pontianak juga sering disingkat dari kata aslinya pada pembicaraan seharihari. Untuk mengetahui jumlah pasti penutur bahasa ini memang sulit didapat, karena tidak ada data yang pasti mengenai jumlah penutur (Indrayana, 2016).

Contoh bahasa Melayu Pontianak yang dikutip dari buku sepok tige karangan Pay Jarot Sujarwo seperti berikut: "Karne lukisan - lukisan Bang Jul ni hamper rate nyritekan tentang Kalbar, secare tak langsong Bang Jul ni ikut jadi duta wisata Kalbar. Maklom, Dinas Pariwisata di tempat kite ni tadak bise bekerje maksimal, jadi kalok ade orangorang barat datang, bukan-e pegi ke pusat inpormasi turis, tapi pegi ke tempat - tempat macam Bang Jul ni."

\section{H. Pengujian Teks Kalimat Metode PoS Tagger}

Pengujian teks kalimat yang lakukan antara kalimat tagging manual yaitu korpus yang telah dikembangkan kemudian dilakukan tagging terlebih dahulu dengan cara manual yaitu sebagai contoh :

"Semue-mue-e tepat waktu."

Kalimat diatas adalah contoh kalimat dari korpus yang telah dikembangakn sehingga berjumlah 1500 kalimat, kemudian dilakukan tagging dengan menambahkan "/, yaitu garis miring dan label kelas kata yaitu tag PoS, sehingga menjadi "Semue-mue-e/PRP tepat/RB waktu/NN ./." hal ini perlu dilakukan agar mesin mengetahui apa jenis kata yang digunakan atau kelas kata yang terdapat pada kalimat tersebut, hal ini dilakukan sebanyak 1500 kalimat semuanya dilakukan tagging secara manual, kemudian akan dilakukan perbandingan antara tagging manual tersebut dengan tagging metode PoS Tagger.

\section{Pengujian Accuracy, Precision, Recall, dan F-Measure}

Precision, dan recall menjadi ukuran yang paling sering digunakan untuk mengevaluasi suatu sistem. Precision adalah rasio jumlah dokumen relevan yang ditemukan dengan total jumlah dokumen yang ditemukan oleh sistem (Rozi, Pramono dan Dahlan, 2012). Nilai precision tertinggi adalah 1, yang berarti seluruh dokumen yang ditemukan adalah relevan (Fitri, 2013). Recall adalah rasio jumlah dokumen relevan yang ditemukembalikan terhadap jumlah seluruh dokumen relevan dalam koleksi (Nugraha, 2014). Nilai recall tertinggi adalah 1, yang berarti seluruh dokumen dalam koleksi berhasil ditemukan. Imam Fahrur Rozi (2012) menjelaskan bahwa, precision adalah rasio jumlah dokumen relevan yang ditemukan dengan total jumlah dokumen yang ditemukan oleh sistem. Recall adalah rasio jumlah dokumen relevan yang ditemukan kembali dengan total jumlah dokumen dalam kumpulan dokumen yang dianggap relevan. Precision dapat dianggap sebagai ukuran ketepatan atau ketelitian, sedangkan recall adalah kesempurnaan. Accuracy merupakan nilai dari keakuratan hasil pengujian dari yang telah dijalankan.

F-measure (nilai F atau F1-Score ) merupakan sebuah nilai dari keakuratan sebuah tes. Nilai $F$ menggunakan 
precision \& recall dari tes untuk menghitung nilainya, dengan precision yang menyatakan jumlah hasil benar dibandingkan dengan jumlah hasil yang ditemubalikkan dan recall yang menyatakan jumlah hasil benar dibandingkan dengan jumlah hasil yang harus ditemubalikkan.

Pengujian accuracy, precision, recall, dan f-measure digunakan untuk mengetahui nilai akurasi keberhasilan PoS Tag terhadap beberapa metode PoS Tagger.

\section{HASIL DAN PENGUJIAN}

\section{A. Hasil Penelitian}

Hasil pengembangan Tag PoS bahasa Melayu Pontianak yaitu tabel PoS dengan jumlah sebanyak 22 set PoS. Set PoS bahasa Melayu Pontianak dapat dilihat pada gambar 2.

\begin{tabular}{|c|c|c|c|}
\hline No & $\operatorname{tag}$ & Deskripsi & Contoh \\
\hline 1 & $\mathrm{NN}$ & nouns & kata benda \\
\hline 2 & NNP & proper nouns & nama, nnama benda atau nama orang, \\
\hline 3 & PRP & Personal Nouns & Saya, aku, dia, kami, orang \\
\hline 4 & VB & Verbs & Makan, tidur, menyanyi, bermain, terdiam, berputar-putar \\
\hline 5 & $\mathrm{JJ}$ & adjective & kata gifat \\
\hline 6 & $\mathrm{RB}$ & adverb & kata keterangan \\
\hline 7 & $\mathrm{CD}$ & Cardinal Number & $\begin{array}{l}\text { ratusan, ribuan, number, satu, dua, kesatu, ketiga, angka } \\
\text { bilangan Rp, \$, Kedua-duanya, ketiga-tiganya, ini, situ, } \\
\text { sana }\end{array}$ \\
\hline 8 & $\mathrm{CDA}$ & Kata Bantu Bilangan & Biji, Ekor, Orang, Buah orang, ton, helai, lembar \\
\hline 9 & CDI & Irregular Numeral & Beberapa, Segala, Semua, BANYAK \\
\hline 10 & CON & Conjunction & $\begin{array}{c}\text { Dan, Atau, Tetapi, sejak, jika, seandainya, supaya, meski, } \\
\text { seolah-olah, sebab, maka, tanpa, dengan, bahwa, yang, lebih } \\
\ldots \text {... daripada.... semoga }\end{array}$ \\
\hline 11 & DT & Determiners & $\begin{array}{c}\text { Para, ini, masing- masing, itu, sang Sri, Sang, Yang, ini, } \\
\text { itu, gini. gitu }\end{array}$ \\
\hline 12 & $\mathrm{IN}$ & Preposition & ke, di, dari, pada, tentang \\
\hline 13 & $\mathrm{MD}$ & Auxiliary(modal) & akan, boleh, sudah, harus, mesti, Bisa \\
\hline 14 & $\mathrm{RP}$ & Particle & Kah, lah, tah, pun, Aduh, astaga, ah, hai, oi \\
\hline 15 & $\mathrm{wH}$ & WH-Determiners & $\begin{array}{c}\text { Apa, siapa, barangsiapa,Apa, siapa, mengapa, } \\
\text { bagaimana, berapa }\end{array}$ \\
\hline 16 & NEG & Negations & Bukan, tidak, belum, jangan \\
\hline 17 & FW & Foreign Word & Music, tidak ketahui \\
\hline 18 & SYM & Symbol & $\left(a \neq \% \%^{\wedge}, \ldots, ;, ;,()\{\}\right] \varnothing-+^{\wedge} \sim \mathrm{Kg}, \mathrm{Gr}, \mathrm{Cm}, \ldots, ?,$. \\
\hline 19 & & TITIK & \\
\hline 20 & & KOMA & \\
\hline 21 & $?$ & Tanda Tanya & \\
\hline 22 & & Tanda geru & \\
\hline
\end{tabular}

Gambar 2. Set PoS Bahasa Melayu Pontianak

Set Pos ini didapatkan dari hasil pengembangan set pos yang dimana pengembangan ini yaitu membandingkan 10 tipe pos dari penelitian lainnya sehingga menghasilkan set pos pada Gambar 2 yang berjumlah 22 .

\section{B. Hasil Pengujian Accuracy, Precision, Recall, dan F- Measure Terhadap Metode PoS Tagger}

Pengujian accuracy, precision, recall, dan F1 dilakukan dengan menggunakan dua buah korpus yang telah di latih sebelumnya. Setiap metode mempunyai korpus latih yang sama dan korpus uji yang sama tetapi memiliki hasil berbeda, karena setiap metode melakukan hasil tagging pada korpus uji dengan mendapatkan data dari korpus latih.

Setelah mendapatkan data tersebut dilakukan pengujian dengan cara menggunakan kode program pada gambar 3.1 dan menggunakan tabel 3.1 untuk melakukan pendataan dari setiap nilai akurasi yang dihasilkan dari setiap metode.

Tabel 2. Nilai akurasi Metode PoS Tagger

\begin{tabular}{|l|l|c|l|l|}
\hline $\begin{array}{l}\text { Metod } \\
\text { e Pos } \\
\text { Tagger }\end{array}$ & $\begin{array}{l}\text { Accuracy } \\
\text { Score }\end{array}$ & $\begin{array}{l}\text { Precisio } \\
\text { n Score }\end{array}$ & $\begin{array}{l}\text { Recall } \\
\text { Score }\end{array}$ & $\begin{array}{l}\text { F- } \\
\text { Measure } \\
\text { Score }\end{array}$ \\
\hline Bigram & 0.950 & 0.921 & 0.962 & 0.941 \\
\hline HMM & 0.975 & 0.984 & 0.973 & 0.978 \\
\hline
\end{tabular}

\begin{tabular}{|l|c|c|c|c|}
\hline $\begin{array}{l}\text { Metode } \\
\text { Pos } \\
\text { Tagger }\end{array}$ & $\begin{array}{c}\text { Accuracy } \\
\text { Score }\end{array}$ & $\begin{array}{c}\text { Precision } \\
\text { Score }\end{array}$ & $\begin{array}{c}\text { Recall } \\
\text { Score }\end{array}$ & $\begin{array}{c}\text { F- } \\
\text { Measure } \\
\text { Score }\end{array}$ \\
\hline $\begin{array}{l}\text { Percept } \\
\text { ron }\end{array}$ & 0.982 & 0.963 & 0.973 & 0.968 \\
\hline $\begin{array}{l}\text { Trigra } \\
\mathrm{m}\end{array}$ & 0.964 & 0.936 & 0.980 & 0.957 \\
\hline $\begin{array}{l}\text { Unigra } \\
\mathrm{m}\end{array}$ & 0.981 & 0.997 & 0.965 & 0.981 \\
\hline
\end{tabular}

Dari tabel 23 dapat dilihat dari tabel diatas untuk nilai accuracy score yang tertinggi adalah Perceptron yang dimana pada metode ini memiliki nilai yang lebih rendah pada pengujian precision, recall, dan f-measure, sedangkan untuk nilai precision tertinggi yaitu dari metode Unigram yang dimana metode ini juga memiliki nilai accuracy yang hanya berbeda 0,001 dari perceptron, sedangkan untuk nilai recall yang tertinggi adalah metode trigram yang memiliki nilai sebesar 0,980 , dan pada pengujian terakhir yaitu fmeasure adalah metode unigram yaitu sebesar 0,981 . Jika kita lihat menggunakan gratik tentunya akan lebih mudah untuk di analisa, sebagai berikut :

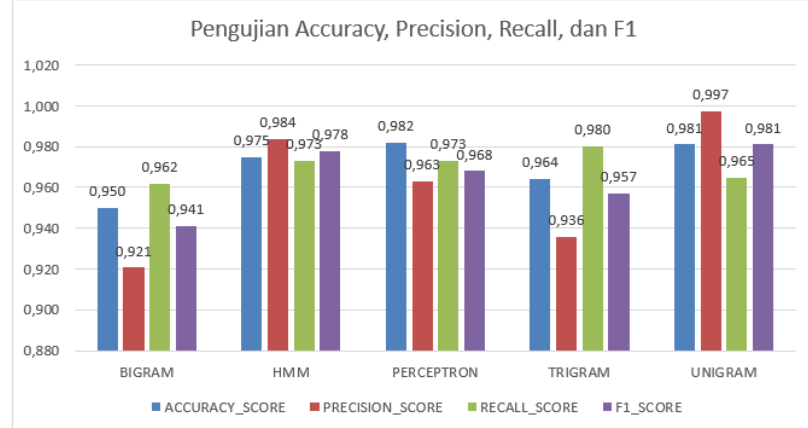

Gambar 4. Grafik Hasil Pengujian Metode PoS Tagger

Dapat dilihat pada grafik gambar 4 Nilai akurasi yang dihasilkan dari setiap metode PoS Tagger yang di uji memberikan nilai terhadap setiap pengujian yang dimana metode unigram memberikan nilai yang lebih tinggi daripada metode lainnya pada pengujian precision dengan nilai 0,997 dan nilai f-measure sebesar 0,981 dan hanya berbeda 0,001 dari metode perceptron pada pengujian accuracy, sedangkan untuk pengujian accuracy metode perceptron memberikan nilai 0,982 , dan untuk pengujian recall metode trigram memberikan nilai tertinggi yaitu sebesar 0,980 .

\section{Analisis Hasil}

Selanjutnya untuk hasil pengujian nilai akurasi dengan perhitungan kalimat 500 kalimat uji dan 500 kalimat latih yang memberikan nilai yang cukup tinggi yang dimana nilai dari setiap metode PoS Tagger berjumlah diatas 0.9. Tag Pos yang telah dikembangkan ini juga memberikan proses yang lebih cepat dalam melakukan perhitungan pengujian karena dengan jumlah tag PoS yang berjumlah 22 dapat mempercepat proses perhitungan dan juga mempercepat dalam proses pengerjaan dalam melakukan tagging karena dengan jumlah tag PoS yang lebih besar akan memberikan beban yang cukup besar dan bagi proses perhitungan dan pengujian yang dimana hal ini tentunya akan memperlambat proses penelitian. 


\section{KESIMPULAN DAN SARAN}

\section{A. Kesimpulan}

Berdasarkan hasil analisis dan pengujian terhadap nilai akurasi metode PoS Tagger untuk bahasa Melayu Pontianak, maka dapat ditarik kesimpulan sebagi berikut : 1. Nilai akurasi yang dihasil dari setiap metode PoS Tagger yang di uji memberikan nilai terhadap setiap pengujian yang dimana metode unigram memberikan nilai yang lebih tinggi daripada metode lainnya pada pengujian precision dengan nilai 0,997 dan nilai f-measure sebesar 0,981 dan hanya berbeda 0,001 dari metode perceptron pada pengujian accuracy, sedangkan untuk pengujian accuracy metode perceptron memberikan nilai 0,982, dan untuk pengujian recall metode trigram memberikan nilai tertinggi yaitu sebesar 0,980 .

\section{B. Saran}

Adapun beberapa hal yang perlu ditambahkan dalam pengembangan penelitian ini adalah sebagai berikut:

1. Perlu dilakukan pengembangan sistem text to speech bahasa Melayu Pontianak dengan manfaatkan tag PoS dari penelitian ini sehingga dapat dilakukan pembangkitan suara oleh sistem TTS.

2. Perlu dilakukan penambahan jumlah korpus dan dilakukan penelitian untuk mendapatkan nilai akurasi jeda terhadap kalimat berdasarkan tag PoS dari penelitian ini.

\section{DAFTAR PUSTAKA}

[1] Abd Wahab Syahroni, Joan Santoso, Endang Setyati. (2017, Agustus 10). Pendekatan Rule Handmade untuk Menentukan Klausa Bahasa Indonesia. Konferensi Nasional Sistem \& Informatika 2017.

[2] Abney, S. P. (1991). Parsing By Chunks, In Robert Berwick, Steven Abney, and Carol Tenny (eds). Kluwer Academic Publishers.

[3] Adriani, M. 2009. Developing Postag for Bahasa Indonesia. PAN Localization Project. Universitas Indonesia.

[4] Arry Akhmad Arman, A. B. (2013). Syntatic Phrase Chunking for Indonesian Language. Bandung: Institut Teknologi Bandung.

[5] Atwell, C. B. (2007). Corpus-Based Evaluation of Prosodic Phrase Break Prediction Using nltk_lite's Chunk Parser to Detect Prosodic Phrase Boundaries in the Aix-MARSEC Corpus of Spoken English. Corpus Linguistics Conference 2007. United Kingdom: University of Birmingham.

[6] Christianti M, V.; Pragantha, J.; dan Victor. 2016. Part-of-Speech Tagging untuk Bahasa Indonesia Menggunakan Stanford POSTagging. Jakarta: Universitas Tarumanegara.

[7] Fitriawati, Lia Suci. 2020. Implementasi Text To Speech Pada Website Menggunakan Metode Shallow Parsing. Pontianak: Universitas Tanjungpura.

[8] Fitri, M. 2013. Perancangan Sistem Temu Balik Informasi dengan Metode Pembobotan Kombinasi TF-IDF untuk Pencarian Dokumen Berbahasa Indonesia. Pontianak: Universitas Tanjungpura.

[9] Handel, V. R. 2008. Uniform Observability of Hidden Markov Models and Filter Stability for Unstable Signals. New Jersey: Universitas Princeton.

[10] Kamiludin, M. I. 2017. Prediksi Jeda pada Ucapan Bahasa Melayu Pontianak dengan Menggunakan Metode Shallow Parsing. Pontianak: Universitas Tanjungpura.

[11] Larasati, S. D.; Kuboň, V.; dan Zeman, D. 2011. Indonesian Morphology Tool (MorphInd): Towards an Indonesian Corpus. Springer CCIS proceedings of the Workshop on Systems and Frameworks for Computational Morphology. Zurich.
[12] Magdalena, Y. 2019. Prediksi Jeda pada Ucapan Kalimat Bahasa Melayu Pontianak Menggunakan Metode Shallow Parsing dengan Pengembangan Rule Grammar dan Rule Jeda. Pontianak, Indonesia

[13] Na'im, A. dan Syaputra, H. 2010. Hasil Sensus Penduduk 2010: Kewarganegaraan, Suku Bangsa, Agama dan Bahasa Sehari-Hari Penduduk Indonesia. Jakarta: Badan Pusat Statistik.

[14] Nugraha, A. T. 2014. Prediksi Jeda dalam Ucapan Kalimat Bahasa Indonesia dengan Hidden Markov Model. Pontianak: Universitas Tanjungpura.

[15] Pisceldo, F.; Adriani, M; dan Manurung, R. 2009. Probabilistic Part Of Speech Tagging for Bahasa Indonesia. Third International Wokshop on Malay and Indonesian Language Engineering. Singapore.

[16] Setyaningsih, E. R. 2017. Part of Speech Tagger untuk Bahasa Indonesia dengan Menggunakan Modifikasi Brill. Surabaya: Sekolah Tinggi Teknik Surabaya.

[17] Wibisono, Y. 2008. Penggunaan Hidden Markov Model untuk Kompresi Kalimat. Bandung: Institut Teknologi Bandung.

[18] Wulandari, Y. 2020. Aplikasi Pelaporan Bantuan Peternakan Di Kabupaten Sambas Dengan Metode Kepustakaan Dan Lapangan. Pontianak : Universitas Tanjung Pura.

[19] Wicaksono, A. F. dan Purwarianti, A. 2010. HMM Based Part-ofSpeech Tagger for Bahasa Indonesia. Proceedings of 4th International MALINDO (Malay and Indonesian Language) Workshop.

[20] Yu, J. dan Tao, J. 2005. The Pause Duration Prediction for Mandarin Text-to-Speech System. China: Chinese Academi of Science. 